\title{
The Behaviour of Health Faculty Students Responding to Hoaxes Related Covid-19 on Social Media
}

\author{
Haikal*, Ratih Pramitasari, Alvin Maulana Firza Yanuar, Nis Syifa'ur Rahma \\ Faculty of Health, Dian Nuswantoro University \\ Pendrikan Kidul, Semarang City, Central Java, Indonesia \\ *corresponding author, e-mail:haikalfaqih@dsn.dinus.ac.id
}

Received: 21/04/21; published: 21/08/21

\begin{abstract}
Background: Hoax is still a problem in the era of information disclosure and technological advances currently. News or information containing hoax related to Covid-19 affects the handling effort of the Covid-19 pandemic. This research aimed to describe the behavior of health faculty students in responding to the hoaxes associated with Covid-19 on social media. Method: This research was a descriptive study. The sampling technique used was random sampling. The samples were 384 students who were required to complete the questionnaire. The statistical test used was descriptive statistical analysis. Results: The results obtained in this study were that respondents considered Facebook as the most widely used social media for spreading hoaxes (68\%). Respondents thought that cross-checking the accuracy and validity of information is a step that should be performed when receiving hoax news $(85 \%)$. Respondents stated that they dug up information through official government websites regarding the handling of Covid-19 to check the statement's truth $(65 \%)$. Some respondents did not cross-check the news or information related to Covid-19 due to the assumption that someone else had done it. Conclusion: Most respondents have cross-checked news or information about Covid-19. Extracting information through official government websites on handling Covid-19 has also been taken to check the accuracy and validity of the statement.
\end{abstract}

Keyword: Health Hoax, Infodemic, Covid-19, Public Health Faculty Students

This is an open access article under the CC-BY-SA license.

\section{Introduction}

Social media users continue to grow every year. For example, Facebook users globally have reached 2,234 billion, and Indonesia is in the third position of Facebook users in the world [1]. Indonesia has 175.4 million internet users, and this number continues to increase every year. The number of active social media users also continues to grow. From 2019 to 2020, this number has increased to reach 160 million users with a penetration rate of $59 \%$ [1]. Many social media users can not filter fake news or hoax. Hoax is still a problem in the era of information disclosure and technological advances currently. Hoaxis a publication that looks like factual news, but in fact, contains lies or slander [2,3]. Hoax spreads much faster than reliable reports. One percent of the most widespread hoaxes can disperse to 1,000 to 100,000 people, while valid information rarely touches more than 1,000 people [3]. A hoax is usually influenced by belief in conspiracy theories. In addition, conspiracy theories have also exacerbated the conditions of the Covid-19 pandemic. If this fear is combined with a desire to blame others and maintain a positive identity for a person or group, this can lead to the emergence and spread of conspiracy theories [4,6-7].

Health is also an object of hoax news. A study showed that health content is in the first rank that contains a lot of hoax information (27\%), followed by political content $(22 \%)$ and entertainment (15\%), respectively. News or information containing hoaxes related to Covid-19 affects the efforts to handle the Covid-19 pandemic [5,9-10]. Covid-19 is a global problem and has an impact on every aspect of people's lives. For example, one of the efforts to manage 
the spread of Covid-19 is by using a mask. However, a hoax said that masks can have a dangerous impact on the body and may cause death, so someone refuses to use a mask $[5,11]$.

Students can be the key to solve the hoax problem in Indonesia. The most significant number of active social media users also comes from students. Students nowadays are known to have the characteristic of being fast in getting the latest information. However, this generation is more focused on looking for information based on wants and tastes. Meanwhile, according to Tom Nichols, one of the factors that caused hoaxes to proliferate was because each person formed their own echo chamber. Each person is trapped in their respective echo chambers and is met with people who have the same understanding [6]. Likely the other internet users, students get information quickly and only seek information based on their wishes. They will soon get trapped in the echo chamber. It is also interesting to see regarding the behavior of health faculty students in responding to the spread of hoax news related to Covid-19. Students in the health faculty are considered to have good knowledge and access to information on issues in the health sector [9]. Based on the background, the researcher will describe the behavior of students of the health faculty at Dian Nuswantoro University in responding to hoaxes related to Covid-19 on social media.

\section{Method}

This research was a descriptive quantitative study as it provides an overview or description of students' behavior in responding to hoax news related to Covid-19. The population in this study was health faculty students with a total of 1,642 people. The research sample was calculated using the Slovin formula with a margin error of $5 \%$ used the random sampling technique. The samples were 384 students who were required to fill the questionnaire completely. The statistical test used was descriptive statistical analysis in a percentage (\%), average (mean), or median or midpoint analysis techniques.

\section{Results and Discussion}

\subsection{Results}

This research classified the characteristics of the respondents in this study based on age, gender, and program study. Based on Table 1, the results showed that most respondents were aged $<20$ years old $(60.41 \%)$. Based on gender, the highest percentage was women $(85.2 \%)$. Based on the origin of the study program with the highest percentage came from S1-Public Health, 259 respondents $(67,4 \%)$. More details can be seen in Table 1.

Table 1.Characteristics of Research Respondents

\begin{tabular}{lcc}
\hline \multicolumn{1}{c}{ Variable } & $\mathbf{n}$ & $\%$ \\
\hline Age $\quad 232$ & 60.41 \\
$\quad<20$ years old & 149 & 38.80 \\
$20-25$ years old & 3 & 0.7 \\
$\quad>25$ years old & & \\
Sex $\quad 57$ & 14.8 \\
$\quad$ Male & 327 & 85.2 \\
$\quad$ Female & & \\
Program Study & 259 & 67.4 \\
$\quad$ S1-Public Health & 102 & 26.6 \\
$\quad$ D3-Medical Records and Health & & \\
$\quad$ Informatics \\
Health Environment & 23 & 6 \\
\hline
\end{tabular}

Based on Table 2, 260 respondents (67.7\%) chose Facebook as the most widely used social media for spreading hoaxes. Two hundred ninety-one respondents $(75.8 \%)$ had been checking the truth when receiving hoax news. Three hundred twenty-five respondents $(84.6 \%)$ had to cross-check the validity of the information received about Covid-1. More details can be seen in Table 2 . 
Table 2.Social Media and Responses of Covid-19 Hoax News

\begin{tabular}{lcc}
\hline \multicolumn{1}{c}{ Variable } & $\mathbf{n}$ & $\%$ \\
\hline Most used Social Media for Hoax Spread & 260 & 67.7 \\
Facebook & 80 & 20.8 \\
Instagram & 1 & 0.26 \\
Line & 32 & 8.33 \\
Twitter & 11 & 2.86 \\
Youtube & & \\
Responses when Receiving Hoax News & 23 & 5.9 \\
Delete immediately & 291 & 75.8 \\
Checking the truth & 39 & 10.2 \\
Silence & 7 & 1.8 \\
Remind the sender & 24 & 6.3 \\
Counter with other news & & \\
Responses when Receiving CovID-19 Hoax News & 11 & 2.9 \\
Directly forward to other people & 14 & 3.6 \\
Instantly do not trust the information received & 325 & 84.6 \\
Cross-check the accuracy of the information received & 6 & 1.6 \\
Add/replace the information obtained into new information & 28 & 7.3 \\
Deleting and silencing received information & & \\
\hline
\end{tabular}

Based on Table 3, 250 respondents (65.1\%) chose to dig up information through the official government website regarding the handling of Covid-19 to verify the news. The most reason for not checking the truth of news related to Covid-19 was that they assumed it had already checked as many as 161 respondents (41.9\%).

Table 3.Checking the Truth of Covid-19 News

\begin{tabular}{lcc}
\multicolumn{1}{c}{ Variable } & $\mathbf{n}$ & $\%$ \\
\hline How to check the truth & 13 & 3.4 \\
Through Mass Media (TV, radio, newspaper) & 15 & 3.9 \\
Through Social Media (WhatsApp, Instagram, Twitter, etc) & 24 & 6.3 \\
Asked directly to relatives who work in the health sector & 24 & 21.4 \\
Asking for information through relatedauthorities (WHO, & 82 & 65.1 \\
IDI, PERSAKMI, IAKMI, etc) & 250 & \\
Asking for information through the official government & & \\
Website regarding the handling of Covid-19 & 121 & 31.5 \\
Reason for not checking the truth & 3 & 0.8 \\
News sent by people you trust & 161 & 41.9 \\
Wants to be the first to tell & 7 & 1.8 \\
Assumed someone had checked & 92 & 24 \\
Do not want to waste internet quota or credit & & \\
Do not want to know or be busy & & \\
\end{tabular}

History of respondents for spreading the Covid-19 Hoax: there were three categories: rarely, sometimes, and never. Rarely is on rare occasions for spreading the Covid-19 Hoax. Sometimes means the respondents would spread the Covid-19 hoax on various occasions. Never is under no circumstances at all to spread the Covid-19 hoax. Based on Table 4, most respondents never spread the Covid-19 hoax (96.1\%). Fifteen samples have spread hoaxes related to Covid-19. Friends became the biggest target for the spread of Covid-19 
hoaxes $(86.6 \%)$. The most common reason was that ten respondents thought the news was trustworthy (66.7\%). More details can be seen in Table 4 .

Table 4.Spread the Covid-19 Hoax

\begin{tabular}{lcc}
\hline \multicolumn{1}{c}{ Variable } & $\mathbf{n}$ & $\%$ \\
\hline History of spreading & 12 & 3.1 \\
$\quad$ Rarely & 3 & 0.8 \\
$\quad$ Sometimes & 369 & 96.1 \\
$\quad$ Never & 1 & \\
Target of spreading & 1 & 6.7 \\
$\quad$ Parents & 13 & 6.7 \\
$\quad$ Unknown People & & \\
$\quad$ Friends & 1 & 6.7 \\
Reason of Spreading & 10 & 66.7 \\
$\quad$ News is obtained from trustworthy people & 4 & 26.6 \\
$\quad$ Think the news is true & & \\
$\quad$ Thought the news was useful & & \\
&
\end{tabular}

\subsection{Discussion}

The number of social media users is increasing every year, and it is effortless to access. Social media is still a place to spread hoaxes. Two hundred sixty respondents $(68 \%)$ consider Facebook the most used social media for hoax spread. It is similar to a report issued by Daily Social, $77.76 \%$ of Facebook users in Indonesia have received hoaxes and are the social media platforms with the highest hoax spread. A large number of users has led to the rapid development of hoaxes. Facebook, as a platform provider, has taken several steps to solve the hoax problem. Closing accounts that spread hoaxes is a step Facebook has taken in Indonesia. Also, actions to change the news feed algorithm have been taken. These steps are also considered quite effective. The interaction ratio for hoax content on Facebook has changed from a range of 40:1, then decreased to 15:1 [8].

Meanwhile, 291 respondents (76\%) said that respondents would check the truth of the news indicated as hoaxes. Examine the truth is one way that can be applied to check news or information. Another way is to increase digital literacy skills. Good digital literacy skills will detect information that is a hoax or not [10,14-15].

Three hundred sixty-nine respondents (96\%) of the total respondents have never disseminated hoax news. The ability to think critically and analyze is one of the assets to prevent the spread of hoaxes [9]. Health Faculty students have been trained to think analytically through learning activities in and outside the classroom. One of which is through field learning experiences 1 and 2 . The low level of education and economy makes them vulnerable to spreading hoaxes [12]. Behavior changes should be doing to anticipate damaging and false information spreading [13].

Based on the spread of hoax news related to Covid-19, friends were the most targeted hoax spread, from 13 respondents (87\%). The use of social media is determined to make friends and strengthen relationships between friends. The intensity of communication between friends on social media has become the cause for the spread of hoax news related to Covid-19. In addition, respondents thought that the reason for spreading Covid-19 hoaxes was that they thought the information was trustworthy $(67 \%)$. Subjective perceptions cannot be used as an indicator to judge the truth of news or information. This subjective perception can result in trapping someone in confirmation bias. Confirmation bias is the tendency for people to seek and believe data that support their views while overriding those that do not [14]. Those in the echo chamber and performing confirmation bias will have difficulty finding comparisons for news or other information. People who believe this fraudulent information tend to be unwilling to protect themselves, making handling the outbreak challenging [15]. A person who believes in hoaxes will tend to accept the information supporting his beliefs and ignore everything against his position [16]. Most of 
the misinformation formats spread on social media are manipulated simply without involving high-level technology such as Artificial Intelligence but only rely on simple photo and video editing applications $[17,26]$.

Three hundred twenty-five respondents (85\%) thought that cross-checking the accuracy of information was a step that should be taken when receiving Covid-19 hoax news. The World Health Organization (WHO) has also launched a risk communication website that contains accurate information and advice that the public can easily understand $[18,25]$. These efforts prepared to overcome the infodemic problem that continues to be troubling. Infodemic is a condition where a flood of information, whether accurate or not, makes it difficult for people to find reliable sources and guides when they need them. Cross-checking news sources, including authors and creators, is also an effort to overcome this infodemic problem $[19,27]$. The best way to fight hoaxes is by flooding news search sources information that is accurate, easy to understand, interesting, and quickly disseminated through media on mobile devices [20,31].

$65 \%$ of respondents stated that they dig up information through official government websites regarding the handling of Covid-19 to check the truth of the news. The Ministry of Information and Communication has made efforts to release a list of hoaxes on the ministry's website, which are carried out regularly and spread via WhatsApp. The Task Force for the Acceleration of Handling Covid-19 has also released a Hoax Buster page that can be referred for accurate information. The formation of a task force for handling Covid-19 facilitates public communication regarding the conditions of the Covid-19 pandemic in Indonesia. Having a responsible authority is better than just trusting news sources with unclear sources. WHO calls this phenomenon of health hoaxes an infodemic and we have to against this. Misinformation of this contagious disease has become a global problem because it can affect people's actions amid the conditions of the Covid-19 pandemic $[21,26]$. In the research evidence hierarchy pyramid, expert opinion is at the lowest position, continued sequentially to the highest hierarchical position are case reports, peer studies, randomized control studies, critical article synopses, critical evidence synthesis, and the highest is systematic review and meta-analysis [22]. Political and business interests can be a source of trusting hoaxes that risk harming consumers if they believe it $[23,28]$.

$42 \%$ of respondents' highest answers revealed that they did not check news or information related to Covid-19 because they thought someone was checking. Social media users must have the ability to assess scientific findings [24,30] critically. Increasing the ability to critically evaluate news or information related to Covid-19 is one thing students can overcome the spread of hoaxes related to Covid-19.

\section{Conclusion}

A large number of users has led to the rapid development of hoaxes. Facebook Inc., as a platform developer, has taken several steps to solve the hoax problem. Closing accounts that spread hoaxes is a step Facebook has taken in Indonesia. Another way to reduce fake news spreading is by increasing digital literacy skills. Digital literacy is the ability of every individual to access, understand, create, communicate, and evaluate information through digital devices. Health Faculty students have been trained to think analytically through learning activities in class and outside the classroom. One of which is through field learning experiences 1 and 2. Most respondents have cross-checked news or information related to Covid-19. Therefore they were extracting information through official government websites on handling covid-19 and verifying the truth of the statement from the experts in their fields. The efforts that students have made in overcoming the spread of hoaxes must be maintained.

\section{References}

1. We Are Social \& Hootsuite. Indonesia Digital report 2020 [Internet]. Glob Digit Insights; 2020. https://datareportal.com/reports/digital-2020-global-digital-overview. (Accessed on July 05, 2021)

2. Hauptman R. A Surfeit of Hoaxes. J Infor Ethics. 2020;29(2):9321. doi: 10.2307/JIE.29.2.8

3. Syahrani R, Boer K. Student's Digital Literacy Abilities Against Hoaxes (A Case Study of University Students in East Kalimantan). ICLSSE. 2021;2018. doi: 10.4108/eai.10-11- 
2020.2303454

4. Vosoughi S, Roy D, Aral S. The Spread of True and False News Online. Science. 2018;359(6380):1146-51. doi: https://doi.org/10.1126/science.aap9559

5. Douglas KM, Sutton RM, Cichocka A. The Psychology of Conspiracy Theories. Curr Dir Psychol Sci. 2017 Dec;26(6):538-42. doi: https://doi.org/10.1177/0963721417718261

6. Romer D, Hall K, Jamieson.Conspiracy Theories as Barriers to Controlling the Spread of COVID-19 in the U.S. Soc Sci Med. 2020;263. doi: https://doi.org/10.1016/j.socscimed.2020.113356

7. Biddlestone M, Green R, Douglas KM. Cultural Orientation, Power, Belief in Conspiracy Theories, and Intentions to Reduce the Spread of COVID-19. Br J Soc Psychol. 2020;59(3):663-73. doi:10.1111/bjso.12397

8. Tasnim S, Hossain MM, Mazumder H. Impact of Rumors and Misinformation on COVID19 in Social Media. J Prev Med public Heal. 2020;53(3):171-4. doi: https://dx.doi.org/10.3961\%2Fjpmph.20.094

9. Pragholapati A. Covid-19 Impact on Students. EdArXiv Prepr. 2020;6:1-6. doi: https://doi.org/10.17605/OSF.IO/NUYJ9

10. Kunjana Rahardi R. Building Critical Awareness of Corona Virus-Related News: CyberPragmatic Study of COVID-19 Hoaxes on Social Media. Int J Adv Sci Technol. 2020;29(6):5398-409. http://sersc.org/journals/index.php/IJAST/article/view/19608

11. Li T, Liu Y, Li M, Qian X, Dai SY. Mask or No Mask for COVID-19: A Public Health and Market Study. PLoS One [Internet]. 2020;15(8 August):1-17. doi: http://dx.doi.org/10.1371/journal.pone.0237691

12. Matz SC. Personal Echo Chambers: Openness-To-Experience is Linked to Higher Levels of Psychological Interest Diversity in Large-Scale Behavioural Data. J Pers Soc Psychol. 2021; doi: https://psycnet.apa.org/doi/10.1037/pspp0000324

13. Allcott $\mathrm{H}$, Gentzkow M, Yu C. Trends in the Diffusion of Misinformation on Social Media. Res Polit. 2019;6(2). doi: https://doi.org/10.1177\%2F2053168019848554

14. Awaliyah AN, Hartati T, Tursiva E. Digital Literation in Increasing Reading Interest and Overcoming Hoax News from Social Media in Basic School Students. 3rd Int Conf Elem Educ (ICEE 2020). 2020;3(November). doi: http://proceedings2.upi.edu/index.php/icee/article/view/1441

15. Susilo ME, Afifi S, Yustitia S. Hoax as a Reflection on the Low Digital Literacy in Indonesia Muhammad. Int Conf Soc Econ Educ Humanit [Internet]. 2019;9:233-237. doi: http://dx.doi.org/10.5220/0009100201650174

16. van Prooijen J. Why Education Predicts Decreased Belief in Conspiracy Theories. Appl Cogn Psychol. 2017;31(1):50-58. doi: https://doi.org/10.1002/acp.3301

17. Khan ML, Idris IK. Recognise Misinformation and Verify Before Sharing: A Reasoned Action and Information Literacy Perspective. Behav Inf Technol. 2019 Dec;38(12):11941212. doi: https://doi.org/10.1080/0144929X.2019.1578828

18. Larson HJ. Blocking Information on COVID-19 Can Fuel the Spread of Misinformation. Nature. 2020;306. doi: https://doi.org/10.1038/d41586-020-00920-w

19. Sude DJ, Pearson GDH, Knobloch-Westerwick S. Self-Expression Just A Click Away: Source Interactivity Impacts on Confirmation Bias and Political Attitudes. Comput Human Behav. 2021;114. doi: http://doi.org/10.1016/j.chb.2020.106571

20. Leng Y, Zhai Y, Sun S, Wu Y, Selzer J, Strover S, et al. Misinformation During the COVID-19 Outbreak in China: Cultural, Social and Political Entanglements. IEEE Trans Big Data. 2021;7(1):69-80. doi: https://doi.org/10.1109/TBDATA.2021.3055758

21. Lazer DMJ, Baum MA, Benkler Y, Berinsky AJ, Greenhill KM, Menczer F, et al. The Science of Fake News. Science (80- ). 2018 Mar;359(6380):1094 LP - 1096. doi: http://science.sciencemag.org/content/359/6380/1094.abstract

22. Evanega S, Lynas M, Adams J, Smolenyak K, Insights CG. Coronavirus Misinformation: Quantifying Sources and Themes in the COVID-19 'Infodemic.' JMIR Prepr. 2020; doi: https://preprints.jmir.org/preprint/28253.

23. Organization WH. Risk Communication and Community Engagement Readiness and Response to Coronavirus Disease (COVID-19): Interim Guidance, 19 March 2020. World Health Organization; 2020. https://apps.who.int/iris/handle/10665/331513

24. Gazendam A, Ekhtiari S, Wong E, Madden K, Naji L, Phillips M, et al. The "Infodemic" of Journal Publication Associated With the Novel Coronavirus Disease. JBJS. 
2020;102(13). doi: 10.2106/JBJS.20.00610

25. Zarocostas J. How to Fight An Infodemic. Lancet. 2020 Feb;395(10225):676. doi: https://doi.org/10.1016/S0140-6736(20)30461-X

26. Setiawan B, Pawito P, Hastjarjo S. Hoax Amidst The Covid-19 Pandemic. ICSSED. 2020;10(November). doi: 10.4108/eai.4-8-2020.2302399

27. Herner M. Perfect Top of the Evidence Hierarchy Pyramid, Maybe Not So Perfect: Lessons Learned by A Novice Researcher Engaging in A Meta-Analysis Project. BMJ evidence-based Med. 2019;24(4):130-142. doi: https://doi.org/10.1136/bmjebm-2018111141

28. Hidayat ML, Listiawati V. The Urgency of Parents Digital Literacy to Prevent Their Children From Harmful Effects of Smart-Mobie Devices. Proceeding Int Conf ChildFriendly Educ. 2018;4:618-622. doi: http://hdl.handle.net/11617/10255

29. Desta TT, Mulugeta T. Living with COVID-19-Triggered Pseudoscience and Conspiracies. Int J Public Health. 2020/06/29. 2020 Jul;65(6):713-4. doi: https://doi.org/10.1007/s00038-020-01412-4

30. Yacoubian HA. Scientific Literacy For Democratic Decision-Making. Int J Sci Educ. 2018;40(3):308-327. doi: https://doi.org/10.1080/09500693.2017.1420266

31. Astuti YD. Digital Literacy Competence of Indonesian Lecturers on Analysis Hoax In Social Media. Libr Philos Pract. 2021;2021(March). doi: https://digitalcommons.unl.edu/libphilprac/5234 